\title{
MONOCRATIZAÇÃO DO SUPREMO \\ E COMPORTAMENTO JUDICIAL: A \\ DELIBERAÇÃO INDIVIDUAL É UMA \\ JUSTIFICATIVA OU UMA ESCOLHA?
}

MONOCRATIZATION OF THE SUPREME COURT AND JUDICIAL BEHAVIOR: IS THE INDIVIDUAL DELIBERATION A JUSTIFICATION OR A CHOICE?

MONOCRATIZACIÓN DEL SUPREMO Y COMPORTAMIENTO JUDICIAL: ¿LA DELIBERACIÓN INDIVIDUAL ES UNA JUSTIFICATIVA O UNA ELECCIÓN?

\section{Lourival Barão Marques Filho'}

Licença CC BY:

Artigo distribuído sob os termos Creative

Commons, permite uso e distribuição

irrestrita em qualquer meio desde que 0 autor credite a fonte original.

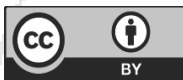

\section{Flávio Garcia Cabral²}

Palavras-chave: Monocratização. Supremo. Comportamento estratégico.

\begin{abstract}
Resumo: Por intermédio do método de abordagem indutivo e do procedimento estatístico, o artigo analisa a monocratização do Supremo Tribunal Federal nas perspectivas quantitativa e qualitativa e demonstra como esse fenômeno, oriundo da competência recursal, dominou o controle concentrado de constitucionalidade. Assim, o que antes poderia ser considerado como uma ferramenta de gestão processual a fim de dar vazão ao volume de demandas que chega ao Tribunal, passou a ser utilizado sob outro cenário: houve uma escolha deliberada de os Ministros não deliberarem coletivamente. Isso ocorre porque exacerbou-se o protagonismo individual, decorrente da adoção do comportamento estratégico dos Ministros. Nesse contexto, o Supremo está aprisionado em um formato decisório que despreza a coletividade e elogia o dissenso.
\end{abstract}

1 Lourival Barão Marques Filho é mestre e doutorando em Direito Econômico e Socioambiental pela PUC/PR. Coordenador e professor do curso de pós-graduação em Direito, processo do trabalho e direito previdenciário da Escola dos Magistrados do Trabalho do Paraná. É Juiz do Trabalho, no Tribunal Regional do Trabalho da $9^{a}$ Região. Atua em Curitiba/PR, Brasil. (lourivalbaraomarques@gmail.com)

2 Flávio Garcia Cabral é pós-doutor pela Pontifícia Universidade Católica do Paraná - PUC/PR; Doutor em Direito Administrativo pela Pontifícia Universidade Católica de São Paulo - PUC/SP; Mestre em Derecho de Daños pela Universitat de Girona - UDG, Espanha. Mestre em Direito Constitucional e Teoria do Estado pela Pontifícia Universidade Católica do Rio de Janeiro - PUC/RJ. Coordenador e professor do curso de Pós-graduação em Direito Público pela Escola de Direito do Ministério Público de Mato Grosso do Sul (EDAMP). Professor da UnigranCapital. Coordenador do Departamento de Direito Administrativo e Constitucional aplicado da Escola Judiciária do TRE/MS. Procurador da Fazenda Nacional. Atua em Campo Grande/MS, Brasil. (flaviocabral_@hotmail.com). 
Abstract: Through the inductive approach and statistical procedure, this article analyzes the monocratization of the Federal Supreme Court in Brazil from quantitative and qualitative perspectives and demonstrates how this phenomenon, which originated with the competence to review, was extended to include constitutional control. Therefore, what was once considered as a tool for managing the high volume of cases seen by the court is now used in another scenario: there was a deliberate choice, by the judges, to not deliberate collectively. This is due to the increase of individual protagonism, arising from the adoption of strategic behavior by the judges. In this context, the Federal Supreme Court is imprisoned in a model of decision-making that runs contrary to collectivity and praises dissent.

Keywords: Monocratic decisions. Supreme Court. Strategic behavior.

Resumen: Por intermedio del método de abordaje inductivo y del procedimiento estadístico, el artículo analiza la monocratización del Supremo Tribunal Federal en las perspectivas cuantitativas y cualitativas y demuestra como este fenómeno, oriundo del órgano jurisdiccional superior, dominó el control concentrado de la constitucionalidad. Así lo que antes podría ser considerado como una herramienta de gestión procesal con el fin de resolver el volumen de demandas que llega al Tribunal, pasó a ser utilizado bajo otro escenario: hubo una elección deliberada de los Ministros, no deliberar colectivamente. Esto ocurre porque se exacerbó el protagonismo individual, debido a la adopción del comportamiento estratégico de los Ministros. En ese contexto, el Supremo está encarcelado en un formato decisorio que desprecia la colectividad y elogia el disentimiento.

Palabras clave: Monocratización. Supremo. Comportamiento estratégico.

\section{INTRODUÇÃO}

O Supremo Tribunal Federal deixou de ser uma Corte que julga coletivamente para se consubstanciar em um Tribunal que decide individualmente, eclipsando, nesse processo, o conceito de colegialidade. Em 2018 o Supremo Tribunal Federal proferiu 126.741 decisões, das quais 112.208 no formato monocrático, o que significa $88,5 \%$ do universo decisório do Tribunal ${ }^{3}$. A série histórica desde 2010 - corte temporal estabelecido pelas estatísticas fornecidas pelo próprio Supremo indica que esse modelo individual está consolidado e, no período de 2010-2018, resultou em 87\% de decisões monocráticas ${ }^{4}$.

O modelo de decisão monocrática foi estabelecido e até mesmo aceito tacitamente pela doutrina e pela sociedade ante o dilúvio de processos que são encaminhados anualmente ao Supremo. De fato, parece ser impossível analisar as dezenas de milhares de agravos e recursos extraordinários cumprindo a integralidade do ritual colegiado e, a fim de dar vazão às demandas, o STF adotou um modelo decisório expedito.

3 BRASIL. Supremo Tribunal Federal. Estatísticas do STF. Disponível em: http://www.stf.jus.br/portal/cms/verTexto. asp?servico=estatistica\&pagina=decisoesinicio. Acesso em: 09 jul. 2019.

4 BRASIL. Supremo Tribunal Federal. Estatísticas do STF. Disponível em: http://www.stf.jus.br/portal/cms/verTexto. asp?servico=estatistica\&pagina=decisoesinicio. Acesso em: 09 jul. 2019. 
Por intermédio do método de abordagem indutivo e do procedimento estatístico, o artigo analisa a monocratização do Supremo Tribunal Federal nas perspectivas quantitativa e qualitativa e demonstra como esse fenômeno, oriundo da competência recursal, dominou o controle concentrado de constitucionalidade. O problema que o artigo enfrenta e procura responder é se a deliberação individual é efetivamente uma ferramenta de gestão do acervo processual ou se ela corporifica outra tendência: a utilização intencional das decisões monocráticas como materialização do comportamento estratégico dos Ministros.

Estrutura-se o estudo em três partes a fim de testar a validade da hipótese de que o Supremo passou a ser marcado pelo voluntarismo e pelo desprezo à colegialidade, porque capturado pelos interesses individuais e estratégicos dos ministros. Na primeira parte são examinadas as competências do Supremo (recursal, originária e constitucional) a fim de demonstrar a disfuncionalidade e a hipertrofia do órgão de cúpula do Judiciário. A seguir, efetua-se uma análise quantitativa das decisões monocráticas e do comportamento na série histórica de 2010-2018 com dupla finalidade: a) mostrar o excesso de individualismo no processo decisório do Supremo e b) identificar um fenômeno recente: a expansão das decisões monocráticas para as demais atuações da Corte. De fato, a monocratização, que foi implantada como resposta à carga recursal, espraiou-se para as demais competências do STF, sobretudo nas ações de controle de constitucionalidade e naquelas demandas com forte impacto político/social/econômico.

Fixada a premissa de que o Supremo se tornou uma Corte que julga individualmente, avançase na investigação, e a segunda parte do estudo tem duas perspectivas: i) busca-se demonstrar qualitativamente como as decisões monocráticas são proferidas em desarmonia com a jurisprudência do Plenário, como as decisões individuais não são encaminhadas para chancela e confirmação colegiada e como o relator utiliza o poder da pauta a fim de atender seus interesses, tendo, assim, o controle da agenda e do timing político-institucional ${ }^{5}$; ii) analisa-se como as deliberações colegiadas possuem essência individual na medida em que a arquitetura do processo de tomada de decisão torna o ambiente do Plenário hostil ao debate, à deliberação e à mútua persuasão.

A terceira e última parte do artigo trata do modelo decisório que atualmente domina o Supremo que se caracteriza pelo comportamento judicial estratégico onde os Ministros possuem agendas jurídico-políticas próprias e individuais ${ }^{6}$, o que resulta em um cenário de desinstitucionalização vertiginoso do órgão.

$5 \quad$ ARGUELHES, Diego Werneck; RIBEIRO, Leandro Molhano. Ministrocracia: O Supremo Tribunal Federal e o processo democrático brasileiro. Novos Estudos Cebrap, v. 37, jan-abr, 2018, p. 20-25. Sobre os poderes do relator, confira SILVA, Virgílio Afonso da. "Um voto qualquer?" O papel do Ministro Relator na deliberação no Supremo Tribunal Federal. Revista Estudos Institucionais, vol. 1, 1, p. 180-200, 2015 e SILVA, Virgílio Afonso da. O relator dá voz ao STF? Uma réplica a Almeida e Bogossian. Revista Estudos Institucionais, vol. 2, 2, p. 648-669, 2016.

6 FALCÃO, Joaquim; ARGUELHES, Diego Werneck. Onze supremos: todos contra o plenário. In: FALCÃO, Joaquim; ARGUELHES, Diego Werneck; RECONDO, Felipe (org.). Onze supremos: o supremo em 2016. Belo Horizonte: Letramento: Casa do Direito: Supra: Jota: FGV Rio, 2017, p. 20-28. No mesmo sentido: NETO, José Mário Wanderley Gomes; LIMA, Flávia Danielle Santiago. OLIVEIRA, Tassiana Moura de. Between Individual Decisions and Collegiate Deliberations: Deciding How To Decide, Influencing the Outcome. Seqüência (Florianópolis). n. 81, p. 10-31, abr. 2019. 


\section{INSULAMENTO E MONOCRATIZAÇÃO: FALÁCIA DO TRIBUNAL NA PERSPECTIVA RECURSAL}

Historicamente a Suprema Corte brasileira condensa três funções essenciais: a) órgão de revisão/cassação, decorrente do modelo clássico da civil law, como tribunal de correção dos tribunais ordinários e com o fito de garantir a unidade do direito objetivo7; b) Corte Constitucional responsável pelo controle constitucional da ordem jurídica; e c) foro judicial especializado para julgar criminalmente as altas autoridades, atuando como verdadeira primeira instância e para apreciar originariamente atos secundários do Parlamento ou do Executivo, podendo, nessa hipótese, funcionar como um tribunal de "pequenas causas políticas".

Essa multiplicidade de funções que ostentam as mais variadas possibilidades processuais contribui decisivamente para uma atuação ineficiente da Corte. De fato, o Supremo atua como primeira instância em ações penais originárias, mas é absolutamente destituído dos mecanismos para a coleta da prova, desenvolvimento, tramitação e julgamento do processo, porquanto possui arquitetura de tribunal e não de órgão monocrático (unidade judicial de primeiro grau). Julga pequenas contendas parlamentares ${ }^{9}$ que não foram - mas deveriam - ser resolvidas no próprio Congresso.

Como tribunal de revisão/cassação, recebe uma carga colossal de recursos extraordinários e agravos em recursos extraordinários (foram 362.949 entre os anos de 2010 a $2018^{10}$ ), que soterram a capacidade de gestão interna. Na qualidade de Corte Constitucional, é responsável pelo julgamento de complexas ações de controle concentrado de constitucionalidade, bem como de demandas que envolvem o núcleo decisório político/social/econômico, mas, ao mesmo tempo, teve que analisar, somente no ano de $2018^{11}$, 13.815 Habeas Corpus e 3.467 reclamações constitucionais, na esmagadora maioria dos casos com pedidos de tutela de urgência.

Esse modelo hipertrofiado de funções impõe um pesado ônus, na medida em que, de um lado, exige produção industrial em ritmo fordista/taylorista e, de outro, demanda decisões artesanais fruto de reflexão e pesquisa.

$7 \quad$ MARINONI, Luiz Guilherme. O julgamento nas cortes supremas: precedentes e decisão do recurso diante do novo CPC. São Paulo: RT, 2015, p. 13.

8 VIEIRA, Oscar Vilhena. "Supremocracia". Revista Direito GV, São Paulo, v. 4, n. 2, jul./dez. 2008, p. 449. No mesmo sentido: GOMES, Juliana Cesario Alvim; NOGUEIRA, Rafaela; ARGUELHES, Diego Werneck. Gênero e comportamento judicial no supremo tribunal federal: os ministros confiam menos em relatoras mulheres? Rev. Bras. Polít. Públicas, Brasília, v. 8, $n^{\circ}$ 2, p. 854-876, 2018. Partindo da mesma premissa, Joaquim Falcão, Diego Werneck Arguelhes e Pablo de Camargo Cerdeira dividem as atividades do Supremo em recursal, ordinária e constitucional (FALCÃO, Joaquim; CERDEIRA, Pablo Camargo; ARGUELHES, Diego Werneck. I Relatório Supremo em números: o múltiplo Supremo. RDA - Revista de Direito Administrativo. Rio de Janeiro, v. 262, jan./abr. 2013, p. 409).

9 VIEIRA, Oscar Vilhena. "Supremocracia". Revista Direito GV, São Paulo, v. 4, n. 2, p. 441-463, jul./dez. 2008.

10 BRASIL. Supremo Tribunal Federal. Estatísticas do STF: ARE, Al e RE. Disponível em: http://www.stf.jus.br/ portal/cms/verTexto.asp?servico=estatistica\&pagina=REAIProcessoDistribuido. Acesso em: 16 jul. 2019.

11 BRASIL. Supremo Tribunal Federal. Estatísticas do STF: Pesquisa por classe. Disponível em: http://www.stf.jus. br/portal/cms/verTexto.asp?servico=estatistica\&pagina=pesquisaClasse. Acesso em: 16 jul. 2019. 
O resultado é facilmente perceptível: o Supremo é um tribunal moroso, imprevisível ${ }^{12}$ e seletivo, que, embora julgue dezenas de milhares de processos, não consegue dar vazão à demanda ${ }^{13}$ e, principalmente, não tem o condão de estabelecer um norte magnético para os graus jurisdicionais inferiores a fim de gerar segurança e estabilidade jurídicas.

Diante dessa conjuntura de massacrante volume processual e competências disfuncionais ${ }^{14}$, o STF paulatinamente foi adotando condutas internas que entendia aptas a solucionar as demandas que Ihe eram submetidas. Tal proceder sempre foi paliativo, precário e intuitivo, porque despido de tecnicidade e de apoio legislativo.

Uma das técnicas adotadas foi a utilização institucional e desenfreada das decisões monocráticas, sobretudo quando atua no formato de tribunal de revisão/cassação.

Essa visão monocrática da competência recursal do Supremo é abordada por um de seus integrantes, o Ministro Luís Roberto Barroso, quando identifica a patológica quantidade de processos e afirma que seria impossível julgá-los no formato deliberativo colegiado clássico. Defende que a decisão monocrática é o mecanismo que o Supremo criou para conseguir apreciar todos os processos que recebe ${ }^{15}$. Institui-se, assim, um modelo que estimula e impulsiona as decisões individuais e desnatura a essência de tribunal na perspectiva originária, ou seja, como órgão de julgamento colegiado ${ }^{16}$.

Ao julgar a esmagadora maioria dos processos sem submissão às Turmas ou ao Plenário, subverte-se o conceito de tribunal, como órgão que reanalisa, revê e reexamina as decisões proferidas pelos tribunais inferiores. A arquitetura institucional do tribunal de revisão/cassação estabelece degraus jurisdicionais que são percorridos pelos usuários do sistema de justiça tendo no vértice o

12 A frequente prática ativista encontrada nos Tribunais brasileiros, com destaque ao STF, acaba por ofender a segurança jurídica em seus caracteres de cognoscibilidade (compreensão das alternativas interpretativas e dos critérios indispensáveis a sua determinação), confiabilidade (a mudança social almejada não pode ocorrer por meio de ataques ao Poder Legislativo e violação à separação dos Poderes) e calculabilidade (capacidade de antecipação do conteúdo das decisões) (FORSTER, João Paulo K.; HAEBERLIN, Mártin. O "iluminismo constitucional": A atuação do Supremo Tribunal Federal entre a autocontenção e o ativismo judicial. Revista Novos Estudos Jurídicos - Eletrônica, vol. 24, n. 2, mai-ago 2019, p. 637).

13 FALCÃO, Joaquim; ARGUELHES, Diego Werneck. Onze supremos: todos contra o plenário. In: FALCÃO, Joaquim; ARGUELHES, Diego Werneck; RECONDO, Felipe (org.). Onze supremos: o supremo em 2016. Belo Horizonte: Letramento: Casa do Direito: Supra: Jota: FGV Rio, 2017, p. 20-28.

14 VIEIRA, Oscar Vilhena. "Supremocracia”. Revista Direito GV, São Paulo, v. 4, n. 2, p. 441-463, jul./dez. 2008.

15 Afirmou o Ministro Luís Roberto Barroso: "A crítica ao excesso de decisões monocráticas é procedente. Do total de decisões proferidas pelo Tribunal em 2016 - incríveis 117 mil -, a imensa maioria foi de natureza monocrática. A explicação é singela: o volume de processos é imenso e o STF realiza cerca de 80 sessões plenárias por ano. Isso significa uma capacidade máxima de julgar cerca de 250 processos anualmente, fazendo o cálculo otimista de três processos por sessão. Como há no estoque do final do ano que se encerrou 61.816 processos pendentes de decisão, só para julgá-los, admitindo-se, contrafactualmente, que não entrasse mais nenhuma causa nova, seriam necessários 247 anos para liquidar o passivo existente. Se contabilizássemos os julgamentos em lista e nas Turmas, esse número diminuiria, mas nada que desfizesse o absurdo. Portanto, resta a alternativa monocrática" (BARROSO, Luís Roberto. O Supremo Tribunal Federal em 2016: o ano que custou a acabar. Disponível em: https://www.conjur.com.br/dl/retrospectiva-2016-barroso-parte.pdf. Acesso em: 16 jul. 2019).

16 Não há dúvida que existe respaldo normativo para a prolação das decisões monocráticas, conforme comando que emerge do art. 21 do Regimento Interno do STF. O que se busca demonstrar no artigo é justamente sua utilização abusiva. 
Supremo como órgão responsável para decidir em última instância ${ }^{17}$. E, nesse modelo, o tribunal foi idealizado como instituição que irá julgar de forma colegiada, afinal, não se imagina que se construa tal pirâmide para que a decisão seja proferida individualmente ${ }^{18}$.

Todavia, o insulamento ministerial é de tal intensidade que em 2018 apenas 11,5\% dos processos foram analisados coletivamente, sendo que os julgamentos pelo Plenário representam índice inferior a $1 \%{ }^{19}$ da movimentação processual, o que dissolve por completo o conceito de colegialidade ${ }^{20}$.

Nesse contexto, na perspectiva de tribunal recursal, o Supremo não atinge minimamente o desiderato para o qual foi planejado e, no trajeto da construção do processo decisório difuso, adquiriu o hábito de decidir individualmente. É dizer, a monocratização não foi suficiente para uma entrega jurisdicional recursal efetiva ${ }^{21}$ e implantou uma racionalidade que cultiva uma hostil incapacidade de deliberar coletivamente.

17 Como assinalam Vera Karam Cheiri e José Arthur Castillo Macedo, "em democracias constitucionais, a Constituição não é o que a Corte Suprema diz que ela é. Há de se considerar que os demais poderes e nós, o povo, são intérpretes tão legítimos da Constituição quanto a Corte e não podemos ser demitidos de tal tarefa" (CHUEIRI, Vera Karam; MACEDO, José Arthur Castillo. Teorias constitucionais progressistas, backlash e vaquejada. Seqüência (Florianópolis). N. 80, dez. 2018, p. 147). Em sentido semelhante: "o poder final não pode ser deixado para o Poder Legislativo, mas também não para o Poder Judiciário. O poder final é 'compartilhado' pelos três poderes em conjunto, em uma relação harmoniosa entre si, e todos eles são responsáveis perante a sociedade civil. Para tanto, é preciso haver diálogo" (SILVA, Virgílio Afonso da. O STF e o controle de constitucionalidade: deliberação, diálogo e razão pública. Revista de Direito Administrativo, v. 250, 2009, p. 220). Confira também: "ainda que os juízes devam sempre ter a última palavra, sua palavra não será melhor por essa razão" (DWORKIN, Ronald. 0 império do direito. 3. ed. São Paulo: Martins Fontes, 2014, p. 492).

18 Nesse sentido leciona Pontes de Miranda: "A regra, para os recursos, é a colegialidade das decisões. Quer dizer: a pluralidade de julgadores, com o fim político de assegurar diversos exames ao mesmo tempo, além do duplo ou múltiplo exame, no tempo, pelo juiz do primeiro grau e os demais juízes superiores. A ciência ensina-nos, hoje, que a assembleia não nos veio da reflexão; foi a reflexão que veio da assembleia. Portanto, o homem é que é produto da assembleia. Essa prioridade do exame múltiplo ao mesmo tempo, em relação ao exame de um só, se transforma em superioridade sempre que desejamos maior certeza. A colegialidade para a decisão dos recursos obedece a esse pendor íntimo do homem quando se deseja guiar pela razão" (PONTES DE MIRANDA, Francisco Cavalcanti. Comentários ao código de processo civil. Tomo VII. Rio de Janeiro: Forense, 1975, p.11).

19 NETO, José Mário Wanderley Gomes; LIMA, Flávia Danielle Santiago. OLIVEIRA, Tassiana Moura de. Between Individual Decisions and Collegiate Deliberations: Deciding How To Decide, Influencing the Outcome. Seqüência (Florianópolis). n. 81, p. 10-31, abr. 2019.

20 Nesse sentido: "(...) a autoridade do Tribunal não pode ser exercida de forma fragmentada por cada um de seus Ministros" (VIEIRA, Oscar Vilhena. "Supremocracia". Revista Direito GV, São Paulo, v. 4, n. 2, jul./dez. 2008, p. 458).

21 No período de 2010 a 2018 o percentual de provimento do recurso extraordinário, agravo em recurso extraordinário e agravo de instrumento em recurso extraordinário foi de 3,18\%. É questionável a manutenção de um órgão julgador que acolhe percentual tão baixo das insurgências recursais, sendo que é justamente essa competência a responsável pela maior quantidade de processos que tramitam na Corte. Confira BRASIL. Supremo Tribunal Federal. Estatísticas do STF: AI, ARE e RE. Disponível em: http://www.stf.jus.br/portal/cms/verTexto.asp?servico =estatistica\&pagina=competenciarecursal. Acesso em: 18 jul. 2019. 


\subsection{EXPANSÃO DA MONOCRATIZAÇÃO: DA COMPETÊNCIA RECURSAL PARA COMPETÊNCIA CONSTITUCIONAL EM CONTROLE CONCENTRADO}

Na série histórica de 2010 a $2018^{22}$ é possível identificar a solidificação da monocratização das decisões no universo decisório do Supremo, aqui incluídas todas as classes processuais. De fato, no período em tela, o menor percentual foi de 84,37\% em 2013 e atingiu o pico em 2017 quando alcançou 89,90\%. É evidente, dessarte, que o Tribunal fragmentou-se a tal ponto que as decisões colegiadas passaram a ser rarefeitas, o que dissipa o conceito de Corte, criando a figura da "jurisprudência solitária" e desequilibrando o cenário institucional. Quantitativamente tem-se as seguintes medidas de decisões monocráticas ${ }^{23}$ :

\begin{tabular}{|l|c|c|c|c|c|c|c|c|c|c|}
\hline \multicolumn{1}{|c|}{ Tipo de decisão } & $\mathbf{2 . 0 1 0}$ & $\mathbf{2 . 0 1 1}$ & $\mathbf{2 . 0 1 2}$ & $\mathbf{2 . 0 1 3}$ & $\mathbf{2 . 0 1 4}$ & $\mathbf{2 . 0 1 5}$ & $\mathbf{2 . 0 1 6}$ & $\mathbf{2 . 0 1 7}$ & $\mathbf{2 . 0 1 8}$ & $\mathbf{2 . 0 1 9}$ \\
\hline COLEGIADA & 11.342 & 13.096 & 12.090 & 14.103 & 17.073 & 17.716 & 14.533 & 12.895 & 14.532 & 8.412 \\
\hline MONOCRÁTICA & 98.358 & 89.313 & 77.773 & 76.150 & 97.382 & 98.944 & 102.953 & 113.623 & 112.208 & 52.866 \\
\hline NÃO INFORMADO & 3 & 18 & 216 & & & & 1 & & 1 & \\
\hline \multicolumn{1}{|c|}{ Soma: } & $\mathbf{1 0 9 . 7 0 3}$ & $\mathbf{1 0 2 . 4 2 7}$ & $\mathbf{9 0 . 0 7 9}$ & $\mathbf{9 0 . 2 5 3}$ & $\mathbf{1 1 4 . 4 5 5}$ & $\mathbf{1 1 6 . 6 6 0}$ & $\mathbf{1 1 7 . 4 8 7}$ & $\mathbf{1 2 6 . 5 1 8}$ & $\mathbf{1 2 6 . 7 4 1}$ & $\mathbf{6 1 . 2 7 8}$ \\
\hline
\end{tabular}

Figura 1: Quantidade de decisões monocráticas e colegiadas. Fonte: STF²4

Inegável, portanto, que está consolidado no processo decisório do Supremo o agir singular, desvinculado dos pares, em verdadeira cruzada solitária, negando-sevalor ao conceito de colegialidade.

O que antes ocorria notadamente na feição recursal do STF, isto é, na análise dos agravos e dos recursos extraordinários, passou também a acontecer nas ações de controle concentrado de constitucionalidade ${ }^{25}$. Isso traz uma nova dinâmica decisória em matérias sensíveis e robustece o protagonismo individual, porquanto amplia os poderes concedidos ao relator. A Figura 2 demonstra justamente a evolução e o crescimento das decisões monocráticas em controle concentrado de constitucionalidade:

22 Quanto mais extensa a série histórica menor a possibilidade de se adotar movimentos cíclicos como indicativos de uma tendência geral (KAZMIER, Leonard J. Estatística aplicada à economia e administração. Trad. Carlos Augusto Crucius; Rev. Técnica Jandyra M. Fachel. São Paulo: Pearson Makron Books, Coleção Schaum, 2004, p. 329).

23 Os dados referentes a 2019 são limitados a junho, último mês cujos dados completos estavam disponíveis no momento da pesquisa.

24 BRASIL. Supremo Tribunal Federal. Estatísticas do STF. Disponível em: http://www.stf.jus.br/portal/cms/verTexto. asp?servico=estatistica\&pagina=decisoesinicio. Acesso em: 09 jul. 2019.

25 Como visto, a monocratização, que iniciou como fenômeno incidente na matéria recursal, alcançou nos últimos anos também as ações de controle abstrato de constitucionalidade. A esse respeito, confira HARTMANN, Ivar Alberto; FERREIRA, Lívia da Silva. Ao relator, tudo: o impacto do aumento do poder do ministro relator no Supremo. Revista Opinião Jurídica, v. 13, n. 17, pp. 268-283, 2015. 


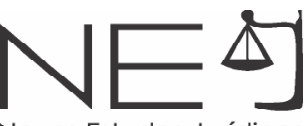

\begin{tabular}{|c|c|c|c|c|c|c|c|c|c|c|}
$\begin{array}{c}\text { Controle } \\
\text { concentrado }\end{array}$ & $\mathbf{2 . 0 1 0}$ & $\mathbf{2 . 0 1 1}$ & $\mathbf{2 . 0 1 2}$ & $\mathbf{2 . 0 1 3}$ & $\mathbf{2 . 0 1 4}$ & $\mathbf{2 . 0 1 5}$ & $\mathbf{2 . 0 1 6}$ & $\mathbf{2 . 0 1 7}$ & $\mathbf{2 . 0 1 8}$ & $\mathbf{2 . 0 1 9}$ \\
\hline ADC & 2 & 3 & 1 & 1 & 2 & 1 & 18 & 10 & 30 & 9 \\
\hline ADI & 169 & 191 & 212 & 262 & 196 & 243 & 248 & 455 & 514 & 310 \\
\hline ADO & 3 & & 6 & 6 & 3 & 3 & 3 & 10 & $\mathbf{8}$ & 3 \\
\hline ADPF & 22 & 23 & 16 & 24 & 28 & 50 & 62 & 92 & 91 & 47 \\
\hline Soma: & $\mathbf{1 9 6}$ & $\mathbf{2 1 7}$ & $\mathbf{2 3 5}$ & $\mathbf{2 9 3}$ & $\mathbf{2 2 9}$ & $\mathbf{2 9 7}$ & $\mathbf{3 3 1}$ & $\mathbf{5 6 7}$ & $\mathbf{6 4 3}$ & $\mathbf{3 6 9}$ \\
\hline
\end{tabular}

Figura 2: Quantidade de decisões monocráticas no controle concentrado. Fonte: STF26

Dentre as quatro classes processuais acima representadas, serão analisadas apenas a ADI (ação direta de inconstitucionalidade) e a ADPF (arguição de descumprimento de preceito fundamental) porque representam a quantidade mais expressiva das ações em controle concentrado e, assim, fornecem melhores elementos para a extração de inferências. As ADC (ação declaratória de constitucionalidade) e ADO (ação direta de inconstitucionalidade por omissão) consubstanciam-se em amostra muito pequena e, ainda, possuem caráter errático, o que poderia gerar resultados inconclusivos. Na ADI, a quantidade de decisões monocráticas aumentou 304,14\% no período 2010-2018 e, na ADPF, elas aumentaram 413,63\%, o que demonstra a evidente opção de individualizar o julgamento das ações de controle concentrado de constitucionalidade. Nesse contexto, a primeira questão a ser analisada é: o aumento das decisões monocráticas acompanhou o crescimento da quantidade das ações de controle concentrado? Isso porque, se o aumento das decisões monocráticas é simétrico com o incremento da quantidade de novas ações de controle concentrado não teria havido mudança de comportamento, mas tão somente repasse do crescimento vegetativo das demandas. A tabela abaixo mostra a evolução da quantidade de novas ADI e ADPF no período de 2010 a 2018:

Tabela 1 - Quantidade de novas ações de controle concentrado (ADI e ADPF) entre 2010 e 2018. Fonte: STF ${ }^{27}$

\begin{tabular}{|c|c|c|}
\hline Anos & ADI & ADPF \\
\hline 2010 & 152 & 18 \\
\hline 2011 & 163 & 20 \\
\hline 2012 & 180 & 25 \\
\hline 2013 & 189 & 34 \\
\hline 2014 & 112 & 15 \\
\hline 2015 & 230 & 48 \\
\hline 2016 & 194 & 59 \\
\hline 2017 & 237 & 68 \\
\hline 2018 & 178 & 54 \\
\hline
\end{tabular}

26 BRASIL. Supremo Tribunal Federal. Estatísticas do STF. Disponível em: http://www.stf.jus.br/portal/cms/verTexto. asp?servico=estatistica\&pagina=decisoesinicio. Acesso em: 09 jul. 2019.

27 RASIL. Supremo Tribunal Federal. Estatísticas do STF: Controle concentrado - dados estatísticos. Disponível em: http://www.stf.jus.br/portal/cms/verTexto.asp?servico=estatistica\&pagina=CC_Geral. Acesso em: 09 jul. 2019. 
De 2010 em diante - que é recorte feito em todas as demais análises das tabelas, gráficos e figuras - verifica-se que o número de ADls aumentou de 152 em 2010 para 178 novas ações em 2018, com forte flutuação no período, variando de 112 novas ações em 2014 até 237 em 2017.

Por sua vez, a ADPF teve crescimento mais constante no período de 2010 a 2018 e, nesse aspecto, saltou de 18 novas demandas em 2010 para 54 em 2018, com pico de 68 novas ações em 2017. Embora tenha havido crescimento quantitativo de novas ações destas classes, o crescimento de decisões monocráticas é muito superior, o que denota e indica a opção feita pelos ministros em julgar individualmente estas demandas. Veja-se que o crescimento das decisões monocráticas na ADI, utilizando o ano base inicial (2010) e final (2018), é de 304,14\% ao passo que a quantidade de novas ADIs cresce 17,80\%. Caso se utilizem os anos com maior variação, ou seja, o vale de 112 novas ações em 2014 e o pico de 237 de 2017, obtém-se um crescimento proporcional de 211,60\%. Em qualquer hipótese, o crescimento das deliberações monocráticas é bem superior.

O mesmo ocorre em relação à ADPF. As decisões monocráticas aumentaram 413,63\% ao passo que a quantidade de novas ações desta classe processual aumentou 300\% quando se consideram os anos bases 2010 e 2018. Fazendo a comparação entre os anos com a menor e maior quantidade de decisões e de novas ações, também se constata crescimento mais expressivo do posicionamento monocrático. O ponto mais baixo de novas ações ocorreu em 2014, com 15 demandas, e o pico em 2017, com 92, o que gera um crescimento de 453,33\%. Já a quantidade de decisões monocráticas teve seu menor valor em 2012, com 12 decisões proferidas, e o máximo em 2017, com 92 decisões individuais. Isso representa uma variação de 575\%. Novamente, em qualquer hipótese, o crescimento das monocráticas é bem superior.

Não se trata, portanto, de mero acréscimo vegetativo do número de decisões monocráticas que acompanha o crescimento de novas ações no Supremo. É possível concluir que se trata de estratégia adotada pelos ministros como modelo de decidir e que não guarda equivalência com o número de novas ações em controle concentrado de constitucionalidade.

De fato, se as decisões individuais tivessem crescido com a mesma intensidade que as novas ações, não teria ocorrido alteração da estratégia adotada pelos julgadores. Porém, como as grandezas são diversas e como as decisões monocráticas se tornaram muito mais comuns e cresceram sem a manutenção da proporção, é factível depreender que outro modelo de julgamento está sendo utilizado: um modelo que prescinde do colegiado. O seguinte gráfico demonstra tal situação: 
A representação gráfica permite visualizar a assincronia de crescimento das decisões monocráticas em comparação com o número de novas ações, notadamente a partir de 2016. Este diagnóstico é referendado pelo Ministro Luís Roberto Barroso, que o denomina de "monocratização qualitativa"28. Esclarece o Ministro que é crescente o "julgamento de casos de maior relevância política, econômica e social para o país de forma monocrática pelos Ministros do Supremo"29.

Replicou-se, assim, o formato de julgamento recursal - monocrático - para as ações de controle de constitucionalidade. Significa dizer que a racionalidade do controle difuso engoliu e ofuscou a dinâmica do controle abstrato e os Ministros passaram a adotar a via monocrática em larga escala nas ADI e ADPF.

\subsection{MONOCRATIZAÇÃO, ELOGIO AO DISSENSO E REPUTAÇÃO} INSTITUCIONAL

Além do cenário quantitativo analisado no item precedente, a monocratização traz outras características e resultados, em especial duas situações que serão em seguida abordadas: a) penúria de deliberação coletiva e ausência de construção de consenso pelo Tribunal como forma de entregar estabilidade, previsibilidade e segurança jurídica; b) a permissão - ainda que oblíqua às decisões individuais contrárias ao entendimento do Plenário ou não submetidas à sua chancela, que, em última análise, significam o absoluto desprezo à jurisprudência da própria Corte e ao modelo institucional construído ${ }^{30}$.

Esse desenho institucional que oportuniza e, até mesmo, estimula o dissenso, acarreta perda de reputação e de legitimidade. De fato, a legitimidade do Judiciário repousa, em sua dimensão formal, na ordem jurídica posta e, na dimensão substancial, na capacidade de justificar suas decisões, apresentando fundamentação adequada, possibilitando, inclusive, o diálogo com os outros atores institucionais, de modo a demonstrar, sobretudo, transparência a fim de afastar a ideia de arbitrariedade ${ }^{31}$. Contudo, a habitualidade de decisões monocráticas que são contrárias à jurisprudência da Corte dissolve a ideia de que o Judiciário se articula e se legitima por intermédio da fundamentação das decisões, afinal, emergem nessa situação outras hipóteses, como seletividade argumentativa e conveniência na justificativa.

28 BARROSO, Luís Roberto. O Supremo Tribunal Federal em 2016: o ano que custou a acabar. Disponível em: https://www.conjur.com.br/dl/retrospectiva-2016-barroso-parte.pdf. Acesso em: 16 jul. 2019.

29 BARROSO, Luís Roberto. O Supremo Tribunal Federal em 2016: o ano que custou a acabar. Disponível em: https://www.conjur.com.br/dl/retrospectiva-2016-barroso-parte.pdf. Acesso em: 16 jul. 2019.

30 Dita forma de agir representa, inclusive, uma afronta ao artigo 926 do CPC, que estabelece que os tribunais devem uniformizar sua jurisprudência e mantê-la estável, íntegra e coerente. A esse respeito, afirma Raúl Eugênio Zaffaroni que "a mais elementar experiência institucional demonstra que sempre que há poder sem controle operase o abuso de poder" (ZAFFARONI, Eugenio Raúl. Poder judiciário: crise, acertos e desacertos. São Paulo: RT, 1995, p. 81).

31 REZENDE, Maurício Côrrea de Moura. Democratização do poder judiciário no Brasil. São Paulo: Contracorrente, 2018, p. 93. No mesmo sentido: GOMES, Luiz Flávio. A dimensão da magistratura: no estado constitucional e democrático do direito. São Paulo: RT, 1997, p. 120. 
Sobre a monocratização e a concentração de poderes individuais nos ministros, Diego Werneck Arguelhes e Leandro Molhano Ribeiro identificam três principais hipóteses: a) tomada de decisão: poder que o relator possui em apreciar medidas liminares sem que haja um controle efetivo pelo Plenário e, ainda, o extenso tempo de duração dessas liminares que acaba por desnaturar sua gênese provisória e precária; b) sinalizações públicas: que podem ser uma mensagem oficial do Tribunal, ou mais sutis, como a fala de um Ministro em um seminário ou entrevista, encorajando ou desencorajando certos tipos de ações e argumentos; e c) definição de agenda: escolher quando julgar uma determinada matéria ou processo, habilitando ou impedindo decisões em momentos específicos $^{32}$. Nesse contexto, "cria-se um espaço, politicamente relevante, de decisão individual sem controle coletivo"33, o que acarreta "judicial review individual, com ministros realizando o controle de constitucionalidade sem qualquer controle efetivo pelo plenário"34.

Nesta toada, três situações que demonstram a hipertrofia do relator e o excesso de monocratização do Supremo serão a seguir analisadas.

\subsubsection{DeCISÕES INDIVIDUAIS QUE NÃO SÃO SUBMETIDAS AO PLENÁRIO}

O exemplo emblemático dessa situação de poder abundante do Ministro em decisão individual e liminar foi a proferida pelo Ministro Joaquim Barbosa quando suspendeu os efeitos da Emenda Constitucional 73/2013³, cuja promulgação culminaria na criação de quatro novos Tribunais Regionais Federais no Brasil.

A EC 73/2013 foi publicada em 06/06/2013 e estabelecia que a instalação dos tribunais deveria ocorrer no prazo de seis meses de sua promulgação. Todavia, em 17/07/2013 foi ajuizada a ADI 5017 pela Associação Nacional dos Procuradores Federais pedindo a declaração de inconstitucionalidade da Emenda Constitucional. A pretensão foi acolhida pelo Ministro Joaquim Barbosa, que determinou a suspensão dos efeitos da EC 73/13. Constou, ainda, na decisão, que após receber as informações do Congresso Nacional, manifestação do Advogado-Geral da União e da Procuradoria-Geral da República a medida cautelar deferida deveria ser submetida ao referendo do Plenário ${ }^{36}$. Passados mais de seis anos, a decisão nunca foi levada ao Plenário para análise pelo colegiado. Tem-se, assim, que um Ministro, em decisão individual, obstou os efeitos de uma Emenda Constitucional, fruto do

32 ARGUELHES, Diego Werneck; RIBEIRO, Leandro Molhano. Ministrocracia: O Supremo Tribunal Federal e o processo democrático brasileiro. Novos Estudos Cebrap, v. 37, jan.-abr, 2018, p. 18.

33 ARGUELHES, Diego Werneck; RIBEIRO, Leandro Molhano. Ministrocracia: O Supremo Tribunal Federal e o processo democrático brasileiro. Novos Estudos Cebrap, v. 37, jan.-abr, 2018, p. 15.

34 ARGUELHES, Diego Werneck; RIBEIRO, Leandro Molhano. Ministrocracia: O Supremo Tribunal Federal e o processo democrático brasileiro. Novos Estudos Cebrap, v. 37, jan.-abr, 2018, p. 15.

35 É tranquilo o entendimento de que o Supremo Tribunal Federal pode exercer o controle de constitucionalidade das emendas constitucionais. Não é essa a matéria em debate aqui, mas sim que a decisão liminar nunca foi referendada pelo Plenário. Sobre a necessidade de quórum qualificado para a declaração de inconstitucionalidade das emendas constitucionais, confira LIMA, Jairo. Emendas constitucional inconstitucionais: democracia e supermaioria. Rio de Janeiro: Lumen Juris, 2018, p. 170 e seguintes.

36 BRASIL. Supremo Tribunal Federal (Presidência). Medida Cautelar na Ação Direta de Inconstitucionalidade 5017. Ministro Joaquim Barbosa, 17 de julho de 2013. Disponível em: http://www.stf.jus.br/arquivo/cms/ noticiaNoticiaStf/anexo/ADI_5017__Liminar.pdf. Acesso em: 07 jul. 2019. 
consenso das duas casas do Poder Legislativo, e a matéria jamais foi novamente debatida. O Ministro Luiz Fux é o relator desde agosto de 2013 e constata-se no andamento processual que os autos estão conclusos desde 11/09/2018 sem referência alguma de que um dia a matéria será debatida pelo Plenário 37 .

Trata-se de demonstração inequívoca de poder excessivo ao Ministro ${ }^{38}$, na medida em que permite a prolação da decisão liminar sem que exista mecanismo de controle e encaminhamento para análise do Plenário que não seja a vontade individual do próprio Ministro-relator ${ }^{39}$. Significa franquear autoridade ao Ministro para decidir e simplesmente nunca encaminhar os autos para chancela do colegiado. É dizer: oportuniza-se que o Ministro-relator profira a decisão, independentemente da jurisprudência do Plenário, suspenda liminarmente uma emenda constitucional e que, depois, a matéria permaneça indefinidamente sem decisão coletiva.

$\mathrm{Na}$ atual arquitetura processual, compete ao relator ou ao Presidente por ocasião do recesso (hipótese presente nesta situação) a prolação de decisão liminar que antecede a decisão colegiada futura ${ }^{40}$, sobretudo porque se espera que os Ministros respeitem a jurisprudência da Corte e, principalmente, que após decidirem sozinhos, levem o processo para a decisão colegiada, afinal, ainda se trata de um tribunal que deve analisar - especialmente em se tratando de controle concentrado de constitucionalidade - os processos de modo coletivo.

A não submissão da decisão liminar à chancela do Plenário demonstra, além do poder monocrático decisório, o poder do relator em estabelecer quando a matéria será analisada. No caso em análise, já se passaram seis anos ${ }^{41}$ e nunca houve análise coletiva da matéria liminar - que deveria ser precária, provisória e efêmera - pelo órgão colegiado. Detém o relator, assim, o poder cronológico da decisão, na medida em que compete exclusivamente a ele a liberação do processo para julgamento plenário, podendo, dessa forma, obstar que a matéria siga para deliberação coletiva, ou ainda, analisar a composição do Plenário a fim de constatar se a sua decisão terá maior possibilidade de prevalecer.

Trata-se, sem dúvida, de escolha de não julgar, que também é uma forma de decisão, e que pode produzir fatos consumados, "aumentando assim os custos de uma decisão judicial futura que

37 BRASIL. Supremo Tribunal Federal. ADI 5017: Andamentos. Disponível em: http://www.stf.jus.br/portal/cms/ verTexto.asp?servico=estatistica\&pagina=decisoesinicio. Acesso em: 09 jul. 2019.

38 Sobre o protagonismo individual dos Ministros, confira: ARGUELHES, Diego Werneck; RIBEIRO, Leandro Molhano. Ministrocracia: O Supremo Tribunal Federal e o processo democrático brasileiro. Novos Estudos Cebrap, v. 37, p. 13-32, jan.-abr, 2018.

39 FALCÃO, Joaquim; ARGUELHES, Diego Werneck. Onze supremos: todos contra o plenário. In: FALCÃO, Joaquim; ARGUELHES, Diego Werneck; RECONDO, Felipe (org.). Onze supremos: o supremo em 2016. Belo Horizonte: Letramento: Casa do Direito: Supra: Jota: FGV Rio, 2017, p. 20-28.

40 ARGUELHES, Diego Werneck; HARTMANN, Ivar A. Mendes e Lula: uma liminar contra o Plenário do Supremo. In: FALCÃO, Joaquim; ARGUELHES, Diego Werneck; RECONDO, Felipe (org.). Onze supremos: o supremo em 2016. Belo Horizonte: Letramento: Casa do Direito: Supra: Jota: FGV Rio, 2017, p. 41-43.

41 Veja-se, também, o caso da ADI 2135 que foi ajuizada em janeiro de 2000 contra a EC 19/1998. O Plenário julgou o pedido cautelar em agosto de 2007 e até o momento não houve julgamento definitivo do mérito. Disponível em: https://legis.senado.leg.br/sdleg-getter/documento?dm=7956312\&ts=1562175713137\&disposition=inline. Acesso em: 08 jul. 2019. 
contrarie esses fatos" 42 . Ao incrementar artificialmente o tempo de julgar, o panorama fático, político e econômico pode se alterar completamente e transformar aquele processo em algo absolutamente indesejável na atual conjuntura, o que acaba, em última análise, a legitimar a não decisão do Ministro ${ }^{43}$. Assim, o "Ministro decide individualmente, e ministro decide individualmente se e quando poderá haver decisão colegiada sobre sua decisão individual" ${ }^{\prime 4}$, fruto da conjugação entre o poder individual e o poder de agenda ${ }^{45}$.

\subsubsection{DeCisões INDIVIdUAIS QUe SÃo CONTRÁRIAS AO PLENÁRIO: O CASO DA EXECUÇÃo PROVISÓRIA DA PENA}

A execução provisória da pena é a matéria que gerou mais discussão, debate e celeuma no âmbito jurisdicional e político nos últimos anos. Após o Plenário mudar de posição, retroagir, evoluir e resgatar entendimento anterior, normalmente por maiorias apertadas, prevaleceu o entendimento de que não é possível a execução provisória da pena antes do trânsito em julgado (ainda que seja plenamente possível as hipóteses legais de prisão preventiva). Pela proposta metodológica deste artigo, não se investigará a (in)correção da decisão, mas tão somente o comportamento dos Ministros e do Plenário no desenvolvimento desta matéria.

\section{A tramitação das Ações Declaratórias de Constitucionalidade 43/DF e 44/DF ${ }^{46}$ ilustra} exemplarmente o excesso de individualismo e o desprezo ao entendimento predominante do Plenário ${ }^{47}$. Em julgamento colegiado ocorrido em 05/10/2016 foi indeferida, por maioria, a cautelar

42 ARGUELHES, Diego Werneck; RIBEIRO, Leandro Molhano. Ministrocracia: O Supremo Tribunal Federal e o processo democrático brasileiro. Novos Estudos Cebrap, v. 37, jan.-abr, 2018, p. 18.

43 Nesse sentido: FALCÃO, Joaquim; ARGUELHES, Diego Werneck. Onze supremos: todos contra o plenário. In: FALCÃO, Joaquim; ARGUELHES, Diego Werneck; RECONDO, Felipe (org.). Onze supremos: o supremo em 2016. Belo Horizonte: Letramento: Casa do Direito: Supra: Jota: FGV Rio, 2017, p. 20-28.

44 ARGUELHES, Diego Werneck; RIBEIRO, Leandro Molhano. Ministrocracia: O Supremo Tribunal Federal e o processo democrático brasileiro. Novos Estudos Cebrap, v. 37, jan.-abr, 2018 p. 25. Com acerto, os autores no mesmo artigo afirmam que "liminares monocráticas-justificadas em princípio como um mecanismo para garantir a autoridade futura da decisão do plenário- podem ser utilizadas no sentido oposto, para neutralizar o controle do plenário sobre uma ação estritamente individual que, hoje, produz efeitos no mundo tomando para si a autoridade da decisão futura que talvez nunca chegue" (ARGUELHES, Diego Werneck; RIBEIRO, Leandro Molhano. Ministrocracia: O Supremo Tribunal Federal e o processo democrático brasileiro. Novos Estudos Cebrap, v. 37, jan.-abr, 2018 p. 14).

45 A fim de alterar esse modelo de perpetuidade de decisões monocráticas sem a chancela colegiada, a PEC 82/2019, dentre outras matérias, veda a concessão de decisão monocrática em controle concentrado de constitucionalidade e estabelece quórum de 2/3 para a declaração de inconstitucionalidade pelo Plenário. Disponível em: https:// legis.senado.leg.br/sdleg-getter/documento?dm=7956312\&ts=1562175713137\&disposition=inline. Acesso em: 08 jul. 2019. Trata-se de reação do Parlamento à atuação desmedida do Supremo, constituindo-se verdadeiro backlash institucional. A esse respeito, confira SUNSTEIN, Cass. R. If people would be outraged by their rulling should judges care? (John M. Olin Program in Law and Economics Working Paper No. 332, 2007); POST, Robert; SIEGEL, Reva. Roe Rage: Democratic Constitucionalism and Backlash. Harvard School, Public Law Working Paper n. 31; DONNELLY, Tom, Making Popular Constitutionalism Work (November 21, 2011). Wisconsin Law Review, Vol. 2012; Harvard Public Law Working Paper No. 11-29. Available at SSRN: https://ssrn.com/ abstract $=1962580$ e CHUEIRI, Vera Karam; MACEDO, José Arthur Castillo. Teorias constitucionais progressistas, backlash e vaquejada. Seqüência (Florianópolis). n. 80, p. 123-150, dez. 2018.

46 BRASIL. Supremo Tribunal Federal. ADC 43: Andamentos. Disponível em: http://portal.stf.jus.br/processos/ detalhe.asp?incidente=4986065. Acesso em: 09 jul. 2019.

47 FALCÃO, Joaquim; ARGUELHES, Diego Werneck. Onze supremos: todos contra o plenário. In: FALCÃO, Joaquim; ARGUELHES, Diego Werneck; RECONDO, Felipe (org.). Onze supremos: o supremo em 2016. Belo Horizonte: Letramento: Casa do Direito: Supra: Jota: FGV Rio, 2017, p. 20-28. 


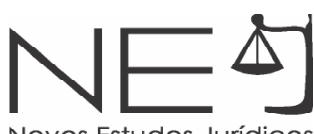

requerida, permitindo desta forma a execução antecipada da pena. Todavia, mesmo diante do posicionamento do Plenário, foram proferidas inúmeras decisões individuais dos Ministros em sentido contrário. Por amostragem qualitativa citam-se as decisões relatadas pelos Ministros Marco Aurélio (ADC 54 MC/DF ${ }^{48}$ ), Gilmar Mendes (HC 153.466/PE ${ }^{49}$ ) e Ricardo Lewandowski (HC 163906/ $\left.\mathrm{MG}^{50}\right)$, que declaradamente não aceitavam a posição estabelecida pelo Plenário e julgaram, de modo deliberado, de forma contrária.

Em 07/11/2019 o Plenário mudou o entendimento e proferiu a decisão final nas Ações Declaratórias de Constitucionalidade 43/DF e 44/DF, reconhecendo a constitucionalidade do art. 283 do Código de Processo Penal e vedando a prisão antes do trânsito em julgado.

Ocorre que, entre a primeira decisão colegiada de 2016 e a decisão final proferida em 2019, existiam Ministros que simplesmente não aceitavam o entendimento fixado inicialmente pelo Plenário no sentido de que era possível (não obrigatório) o cumprimento imediato da pena e decidiam individualmente em oposição à tese colegiada.

Não deveria existir espaço aqui para voluntarismo, tampouco vaidade intelectual, porquanto a Corte Constitucional deve ser mais do que a soma da vontade individual; devendo, pelo contrário, representar uma instituição que transmita seriedade, segurança, previsibilidade e transparência. No atual momento de evolução do Direito, não é mais aceitável a loteria jurisprudencial que definirá se o usuário do sistema de justiça permanecerá encarcerado ou livre conforme a sorte de seu processo ser distribuído para um Ministro que é resistente e relutante em aceitar a posição da maioria.

Nem se alegue que a possibilidade de julgar em desarmonia com o Plenário é uma faceta da independência do magistrado. A Constituição Federal de 1988 conferiu substancial independência ${ }^{51}$ ao Poder Judiciário, assegurando garantias institucionais, funcionais e proteção à imparcialidade ${ }^{52}$, e nenhuma dessas perspectivas autoriza a adoção de entendimento individual contrário ao Plenário. A independência é voltada para a possibilidade de o juiz ter assegurada a possibilidade de exercer sua função com segurança e sem ser alvo de retaliação (interna e externa).

48 BRASIL. Supremo Tribunal Federal. Medida Cautelar na Ação Declaratória de Constitucionalidade 54/ DF. Relator: Ministro Marco Aurélio, 19 de dezembro de 2018. Disponível em: http://portal.stf.jus.br/processos/ downloadPeca.asp?id=15339307371\&ext=.pdf. Acesso em: 07 jul. 2019.

49 BRASIL. Supremo Tribunal Federal. Habeas Corpus 153466/PE. Relator: Ministro Gilmar Mendes. Disponível em: http://portal.stf.jus.br/processos/downloadPeca.asp?id=313882237\&ext=.pdf. Acesso em: 07 jul. 2019.

50 BRASIL. Supremo Tribunal Federal. Habeas Corpus 163906/MG. Relator Ministro Ricardo Lewandowski. Disponível em: http://portal.stf.jus.br/processos/downloadPeca.asp?id=15339137071\&ext=.pdf. Acesso em: 07 jul. 2019.

51 Sobre o conceito de independência do juiz, confira GOMES, Luiz Flávio. A dimensão da magistratura: no estado constitucional e democrático do direito. São Paulo: RT, 1997, p. 36 e DALLARI, Dalmo de Abreu. $O$ poder dos juízes. São Paulo: Saraiva, 1996, p. 44.

52 TOMIO, Fabrício Ricardo de Limas; ROBL FILHO, Ilton Norberto. Accountability e independência judiciais: uma análise da competência do Conselho Nacional de Justiça (CNJ). Revista de Sociologia e Política [online]. vol.21, n. 45,2013, p. 29. 
Mais do que mera disciplina judiciária, deve ocorrer deferência à instituição que existe no ápice do sistema de justiça e que possui representatividade e legitimidade perante a sociedade. É a construção de consensos que gera segurança e, principalmente, estabilidade nas decisões ${ }^{53}$, na medida em que sinaliza para todo o sistema de justiça o posicionamento do tribunal sobre a matéria e que ela será obedecida por todos os seus componentes ${ }^{54}$.

Neste diapasão, a concessão de decisões monocráticas contrárias à posição do Plenário demonstra: a) indiferença pela jurisprudência da Corte; b) desdém pela instituição; c) desrespeito à ideia de colegialidade; d) excesso de protagonismo individual; e) insegurança e instabilidade jurídicas.

\subsubsection{DELIBERAÇÕES COLEGIADAS DE ESSÊNCIA INDIVIDUAL}

Além do desmoderado número de processos julgados monocraticamente, das liminares que não são submetidas ao Plenário ou que ostentam posicionamento contrário ao do colegiado, existe, ainda, outra matéria que merece análise na questão que envolve o individualismo dos Ministros. Isso decorre da forma como as decisões coletivas são construídas, o que, na prática, resulta não em um consenso entre os juízes sobre a matéria, mas sim, a indicação de onze soluções que não dialogam entre si, de onde é difícil (às vezes impossível) estabelecer com precisão a ratio decidendi ${ }^{55}$.

O processo de deliberação coletivo do Supremo não estimula o debate, muito menos o convencimento de um Ministro por outro. Como os votos são adrede preparados por escrito ${ }^{56}$ as sessões plenárias acabam sendo intermináveis leituras de votos ${ }^{57}$, onde cada Ministro apenas

53 EPSTEIN, Lee; SEGAL, Jeffrey; SPAETH, Harold. The norm of consensus on the U.S. Supreme Court. American Journal of Political Science, vol. 45, n. 2, p. 362-377, (Apr., 2001). Também nesse sentido: "A força da Constituição está ligada à estabilidade das decisões do Supremo Tribunal Federal” (MARINONI, Luiz Guilherme. Precedentes obrigatórios. 2. ed. São Paulo: RT, 2011, p. 461).

54 "É preciso que um tribunal superior, no exercício do controle de constitucionalidade, fale 'como instituição', de forma 'clara', 'objetiva', 'institucional' e, sempre que possível, 'única'. Esse é o papel da deliberação interna" (SILVA, Virgílio Afonso da. O STF e o controle de constitucionalidade: deliberação, diálogo e razão pública. Revista de Direito Administrativo, v. 250, 2009, p. 211).

55 Flávia Portella Püschel, ao analisar os votos proferidos da ADPF 54, consigna que "o que se tem são posições individuais acerca do conceito de vida. A decisão final com relação a este ponto não tem nenhum fundamento racional coletivo e, portanto, não consagra nenhuma posição do tribunal a respeito do que seja vida ou morte no direito brasileiro, capaz de vincular possíveis decisões futuras acerca de casos considerados semelhantes" (PÜSCHEL, Flavia Portella. Racionalidade coletiva no STF e precedentes vinculantes: o exemplo do conceito de vida na ADPF n. 54. Revista Novos Estudos Jurídicos - Eletrônica, Vol. 24 - n. 2, mai-ago 2019, p. 548).

56 "Há um problema sério em deliberar a partir do voto escrito do relator e, mais ainda, dos votos escritos dos vários membros do colegiado. É certo que essa é a prática atual das nossas Cortes Supremas. Contudo, esse modo de articular o julgamento pode ser um obstáculo à adequada deliberação" (MARINONI, Luiz Guilherme. O julgamento nas cortes supremas: precedentes e decisão do recurso diante do novo CPC. São Paulo: RT, 2015, p. 104).

57 Como afirmou um Ministro ouvido sob a condição de anonimato em pesquisa conduzida por Virgílio Afonso da Silva: "Eu creio razoável a proposta do Luís Roberto Barroso de dar um prazo para o voto. Isso obrigaria um certo poder de síntese. [ninguém poderia ficar] lendo o voto, nem lembrando João Sem Terra..." (SILVA, Virgílio Afonso da. "Um voto qualquer?" O papel do Ministro Relator na deliberação no Supremo Tribunal Federal. Revista Estudos Institucionais, vol. 1, 1, 2015, p. 193). 
espera o momento de ser chamado para apresentar sua posição. Não se cria, nesse contexto, um ambiente propício para a argumentação e persuasão, senão mero palco de apresentação de decisões previamente fixadas ${ }^{58}$. Como bem ressalta Virgílio Afonso da Silva ${ }^{59}$, praticamente não há troca de argumentos entre os Ministros, uma vez que, nos casos mais relevantes, os votos são levados prontos e os membros do STF não estão ali para ouvir os colegas de Tribunal, mas somente para apresentar sua posição antecipadamente definida. Alia-se a isso a inexistência de unidade institucional e decisória, porquanto o Supremo não julga como instituição, mas como a soma dos votos individuais e, por fim, a carência de decisões claras, objetivas e que veiculem a decisão do tribunal. Isso porque, como reflexo da ausência de unidade decisória, as decisões do STF são publicadas como uma soma, uma "colagem" das decisões individuais, de onde é difícil desvendar as razões de decidir do tribunal na qualidade de instituição60.

Nega-se, assim, a possibilidade de um diálogo frutífero ${ }^{61}$, já que a justificativa prévia escrita é a antítese da faculdade do convencimento entre os magistrados e da tomada de decisão pautada na argumentação dos demais ${ }^{62}$. Como afirma Luiz Guilherme Marinoni, "não há racionalidade em ter uma decisão que antecede a discussão e uma justificativa escrita antes da decisão final colegiada. O relator deve redigir um projeto de julgamento e uma proposta de voto, um convite à discussão e não um convite à adesão"63.

58 Essa situação foi potencializada com a transmissão ao vivo das sessões de julgamento. Pesquisa empírica realizada por Felipe de Mendonça Lopes conclui que a partir das transmissões pela televisão há comprovação de que os juízes passam a agir como políticos utilizando a mídia televisiva com o fito de aumentar sua exposição individual. Em razão disso, os votos ficaram cada vez maiores (LOPES, Felipe de Mendonça. Television and Judicial Behavior: Lessons from the Brazilian Supreme Court. Economic Analysis of Law Review, v. 9, n. 1, p. 41-71, jan-abr, 2018).

59 SILVA, Virgílio Afonso da. O STF e o controle de constitucionalidade: deliberação, diálogo e razão pública. Revista de Direito Administrativo, v. 250, 2009, p. 217.

60 SILVA, Virgílio Afonso da. O STF e o controle de constitucionalidade: deliberação, diálogo e razão pública. Revista de Direito Administrativo, v. 250, 2009, p. 217.

61 MARINONI, Luiz Guilherme. O julgamento nas cortes supremas: precedentes e decisão do recurso diante do novo CPC. São Paulo: RT, 2015, p. 104-105.

62 Em pesquisa que ouviu 17 Ministros da ativa e aposentados e cuja divulgação dos posicionamentos deles é anônima, um dos magistrados afirmou que "dificilmente um ministro vai reconsiderar, porque ele não espera os outros argumentos, ele já põe o ponto de vista dele e ele vai para lá para defender aquele ponto de vista a qualquer preço". Na mesma pesquisa é possível verificar a diferença entre os atuais Ministros - que consideram normal levar votos escritos - com os Ministros aposentados, que salientam que, na sua época, só o relator levava o voto pronto (SILVA, Virgílio Afonso da. "Um voto qualquer?" O papel do Ministro Relator na deliberação no Supremo Tribunal Federal. Revista Estudos Institucionais, vol. 1, 1, 2015, p. 191).

63 MARINONI, Luiz Guilherme. O julgamento nas cortes supremas: precedentes e decisão do recurso diante do novo CPC. São Paulo: RT, 2015, p. 105. Correta a crítica de Virgílio Afonso da Silva no sentido de não fazer sentido o relator não disponibilizar seu voto antes da sessão para os demais Ministros, porquanto é ele quem mais se ocupou do caso e estudou a matéria (SILVA, Virgílio Afonso da. "Um voto qualquer?" O papel do Ministro Relator na deliberação no Supremo Tribunal Federal. Revista Estudos Institucionais, vol. 1, 1, 2015, p. 193). Sobre o processo de elaboração dos votos na Suprema Corte americana, João Carlos Souto explica que "na medida em que o voto é redigido, ele passa de mãos em mãos, entre os ministros. Essa etapa pode durar meses e nela é possível ocorrer mudança de entendimento por um ou mais ministros, vale dizer, eles podem alterar o entendimento anteriormente defendido durante a conferência. Essa prática de o rascunho (draf) de cada voto circular entre os ministros, que não raro elaboram observações sobre esse ou aquele aspecto do voto de outro, demonstra o caráter dinâmico e efetivamente colegiado da Corte e demonstra mais a construção conjunta do resultado. Nessa fase, a maioria do case conference pode se tornar uma minoria, e vice-versa. Na penúltima etapa, os Justices finalizam seus votos, apoiando a maioria ou juntando-se à dissidência (dissenting opinion). Nessa fase, é feito o último esforço no sentido de se obter a maioria. Trata-se de uma fase praticamente final, logo em seguida ao case conference" (SOUTO, João Carlos. Suprema corte dos Estados Unidos: principais decisões. 3. ed. São Paulo: Atlas, 2019, p. 85-86). 
Tem-se, dessarte, decisões coletivas de essência individual, porquanto o debate e o ônus argumentativo voltado ao convencimento são rarefeitos, praticamente inexistentes. Nesse contexto, constata-se mais uma faceta do individualismo, uma vez que, mesmo nas sessões colegiadas, julgase isoladamente. Poderiam os Ministros votar em cabines separadas, porque ninguém conhece previamente o voto do outro e tampouco se propõem a escutar e alterar o voto já elaborado.

Uma solução parcial é proposta por Virgílio Afonso da Silva ${ }^{64}$, em pesquisa na qual entrevistou dezessete Ministros da ativa e aposentados sobre o papel do relator. Salienta o autor que houve maioria entre os Ministros ouvidos no sentido de que a entrega do voto do relator aos demais membros previamente à sessão seria frutífera na medida em que não seria necessário produzir longos votos prontos para a sessão, além de diminuir seu tempo de duração. De fato, ao conhecer previamente o entendimento do relator e se o Ministro concorda com aquela posição, ele seria poupado de produzir um voto por escrito e lê-lo na sessão. Nesse sentido, a deliberação "poderia ter um centro e o processo decisório no STF poderia deixar de ser a soma de 11 votos que não dialogam entre si" ${ }^{\prime 65}$. Essa hipótese tem a vantagem de prescindir de qualquer alteração legal e/ou constitucional.

\section{MONOCRATIZAÇÃO E COMPORTAMENTO JUDICIAL}

Se, inicialmente, a monocratização poderia ser considerada como resposta à avalanche processual - sobretudo recursal -, como mecanismo construído a fim de dar vazão à demanda, a habitualidade deste formato demonstra que, sob aquela justificativa, essa forma de agir resulta, na verdade, em estratégia individual com o fito de fazer prevalecer o entendimento individual, mesmo - e especialmente - quando existe decisão colegiada prévia em sentido contrário ${ }^{66}$. De fato, paulatinamente houve mutação no formato decisório nas ações de controle de constitucionalidade tomando forma e corpo o modelo monocrático, mantendo-se afastado do controle do plenário ${ }^{67}$.

Compreende-se por decisão monocrática liminar aquela proferida pelo Ministro, por delegação do poder do Plenário, em matéria que demanda urgência. Dada sua gênese transitória e revogável ${ }^{68}$ elas devem representar a própria posição do colegiado que somente não a profere ante a premência

64 SILVA, Virgílio Afonso da. "Um voto qualquer?" O papel do Ministro Relator na deliberação no Supremo Tribunal Federal. Revista Estudos Institucionais, vol. 1, 1, p. 180-200, 2015.

65 SILVA, Virgílio Afonso da. "Um voto qualquer?" O papel do Ministro Relator na deliberação no Supremo Tribunal Federal. Revista Estudos Institucionais, vol. 1, 1, 2015, p. 199. No mesmo sentido: SILVA, Virgílio Afonso da. De quem divergem os divergentes: os votos vencidos no Supremo Tribunal Federal. Direito, Estado e Sociedade, $\mathrm{n}$. 47, p. 205-225, jul/dez 2015.

66 FALCÃO, Joaquim; ARGUELHES, Diego Werneck. Onze supremos: todos contra o plenário. In: FALCÃO, Joaquim; ARGUELHES, Diego Werneck; RECONDO, Felipe (org.). Onze supremos: o supremo em 2016. Belo Horizonte: Letramento: Casa do Direito: Supra: Jota: FGV Rio, 2017, p. 20-28.

67 FALCÃO, Joaquim; ARGUELHES, Diego Werneck. Onze supremos: todos contra o plenário. In: FALCÃO, Joaquim; ARGUELHES, Diego Werneck; RECONDO, Felipe (org.). Onze supremos: o supremo em 2016. Belo Horizonte: Letramento: Casa do Direito: Supra: Jota: FGV Rio, 2017, p. 20-28.

68 FALCÃO, Joaquim; ARGUELHES, Diego Werneck. Onze supremos: todos contra o plenário. In: FALCÃO, Joaquim; ARGUELHES, Diego Werneck; RECONDO, Felipe (org.). Onze supremos: o supremo em 2016. Belo Horizonte: Letramento: Casa do Direito: Supra: Jota: FGV Rio, 2017, p. 20-28. 
temporal. É disfuncional um modelo que outorga poder monocrático - que provém da instituição para decidir em desacordo com a própria instituição e, sobretudo, que não possua ferramentas de constrangimento para evitar que tal situação ocorra.

A monocratização das decisões (88,5\% em 2018), com aumento expressivo no controle concentrado, é uma das mais visíveis facetas dessa circunstância. Com efeito, os Ministros passaram a desenvolver suas próprias agendas jurisprudenciais, sem a chancela do colegiado, o que espelha o exercício individual de poder ${ }^{69}$. Joaquim Falcão e Diego Werneck Arguelhes defendem que, diante da fragmentação do Tribunal, decorrente das disputas políticas e formações de alianças dentro e fora do Supremo, os Ministros passaram a adotar um comportamento político estratégico individual ${ }^{70}$, afirmando, ainda, que isso resultou em "apropriação individual de um poder institucional"71.

Acerca do comportamento judicial, são catalogados três principais modelos: a) jurídico 72 ; b) atitudinal ${ }^{73}$ e c) estratégico. Pelos limites deste artigo aprofunda-se a investigação sobre o último.

O modelo estratégico reconhece que o juiz é pautado por suas preferências políticasideológicas, mas avança para acentuar que os magistrados são atores sociais sofisticados ${ }^{74}$ que efetuam cálculo estratégico no sentido de adotar posturas que resultem na maior probabilidade de

69 ARGUELHES, Diego Werneck; RIBEIRO, Leandro Molhano. O Supremo Individual: mecanismos de atuação direta dos Ministros sobre o processo político. Direito, Estado e Sociedade, n. 46, jan/jun, 2015, p. 139.

70 FALCÃO, Joaquim; ARGUELHES, Diego Werneck. Onze supremos: todos contra o plenário. In: FALCÃO, Joaquim; ARGUELHES, Diego Werneck; RECONDO, Felipe (org.). Onze supremos: o supremo em 2016. Belo Horizonte: Letramento: Casa do Direito: Supra: Jota: FGV Rio, 2017, p. 20-28. No mesmo sentido: NETO, José Mário Wanderley Gomes; LIMA, Flávia Danielle Santiago. OLIVEIRA, Tassiana Moura de. Between Individual Decisions and Collegiate Deliberations: Deciding How To Decide, Influencing the Outcome. Seqüência (Florianópolis). $\mathrm{n}$. 81, p. 10-31, abr. 2019.

71 FALCÃO, Joaquim; ARGUELHES, Diego Werneck. Onze supremos: todos contra o plenário. In: FALCÃO, Joaquim; ARGUELHES, Diego Werneck; RECONDO, Felipe (org.). Onze supremos: o supremo em 2016. Belo Horizonte: Letramento: Casa do Direito: Supra: Jota: FGV Rio, 2017, p. 20-28.

72 Pelo modelo jurídico, o que impulsiona e move o magistrado no processo da construção da decisão é a análise da ordem jurídica posta. O juiz ao decidir procura exclusivamente a resposta no ordenamento jurídico e questões que não orbitem no mundo jurídico lhe são irrelevantes (POSNER, Richard A. How judges think. Cambridge: Harvard University Press, 2010, p. 8).

73 Por sua vez, o modelo atitudinal indica que o juiz é movido por questões ideológicas e políticas e, portanto, ao julgar não se despe das influências que recebeu de diversas esferas durante a construção da sua personalidade. Embora argumente juridicamente, a decisão tem inafastável color ideológico. Nesse contexto, o juiz não se limita a investigar a matéria no domínio jurídico, mas sim avança e arquiteta a decisão cotejando todas as influências que recebeu durante sua vida. Nesse sentido: POSNER, Richard A. How judges think. Cambridge: Harvard University Press, 2010, p. 20 e ZARONI, Bruno Marzullo. Deliberação e julgamento colegiado: uma análise do processo decisório do STF. 2015. Tese (Doutorado em Direito) - Faculdade de Direito, Universidade Federal do Paraná, Curitiba, 2015. p. 24. Com igual intelecção: "No modelo atitudinal, portanto, o direito não se configura nem como restrição, nem motivação. Ele é apenas uma racionalização ex post que justifica a tomada de uma decisão baseada em uma predisposição política do juiz (predisposição esta mensurável através de sua ideologia pessoal)" (ARGUELHES, Diego Werneck; RIBEIRO, Leandro Molhano. Preferências, Estratégias e Motivações: pressupostos institucionais de teorias sobre comportamento judicial e sua transposição para o caso brasileiro. Revista Direito e Práxis. Vol. 4, n. 7, 2013, p. 99). Em idêntica toada, veja também MELLO, Patrícia Perrone Campos. "A vida como ela é": comportamento estratégico nas cortes. Rev. Bras. Polít. Públicas, Brasília, v. 8, $n^{\circ}$ 2, p.688-718, 2018.

74 ZARONI, Bruno Marzullo. Deliberação e julgamento colegiado: uma análise do processo decisório do STF. 2015. Tese (Doutorado em Direito) - Faculdade de Direito, Universidade Federal do Paraná, Curitiba, 2015. p. 28. De igual modo, confira: MELLO, Patrícia Perrone Campos. "A vida como ela é": comportamento estratégico nas cortes. Rev. Bras. Polít. Públicas, Brasília, v. 8, n² 2, p.688-718, 2018. 
que sua preferência individual se sagre vencedora ${ }^{75}$. Esse modelo tem duas dimensões. A dimensão interna diz respeito às oportunidades em que o juiz atua para que seu voto seja vencedor e, para tanto, pode adotar as seguintes condutas (dentre outras): a) analisar o perfil dos demais juízes visando antecipar quais serão seus posicionamentos; b) verificar as decisões anteriores dos Ministros a fim de constrangê-los em não apresentar decisão diversa; c) constatar a composição momentânea do órgão julgador a fim de que existam mais juízes que concordem com ele; d) não liberar os autos para análise do Plenário ${ }^{76 ;}$ e) retirar os autos em vista e, com isso, redefinir o timing da decisão; e.1) não observar o prazo regimental e não devolver os autos de vista; f) construir um voto médio (que não representa exatamente o que ele entende sobre a matéria), mas que signifique um caminho mais fácil para ser acompanhado pelos demais juízes; g) construir individual e artificialmente jurisprudência ${ }^{77}$; h) "emparedar o Plenário"78, tornando mais custosa a decisão colegiada contrária à monocrática; i) julgar contrariamente à jurisprudência do Plenário ou das Turmas; j) no caso da Presidência, não incluir os autos na pauta do Plenário ${ }^{79}$ após a liberação pelo relator; j.1) ser o juiz "antinatural" durante o recesso responsável pelas decisões que envolvam tutela de urgência.

Já na dimensão externa, o juiz atua fora do tribunal com o fito de influenciar a esfera políticojurídica. Isso pode ocorrer (dentre outras hipóteses): a) mediante palestras ou entrevistas onde o Ministro indica previamente seu entendimento sobre a matéria e já sinaliza qual será sua decisão ${ }^{80}$, ofertando aos usuários do sistema judicial a ciência prévia do resultado de sua pretensão; b) mediante exposição pública o Ministro declara antecipadamente que determinado projeto que está sendo discutido no Parlamento será considerado inconstitucional, o que, sem dúvida, desencoraja a aprovação ${ }^{81}$.

Todos esses comportamentos se fortalecem quando o Tribunal deixa de atuar na perspectiva colegiada e passa a funcionar individualmente, porque franqueia ao Ministro um feixe de opções mais alargado a fim de construir sua agenda própria.

Ao se admitir que o Tribunal julgue monocraticamente, inclusive em controle concentrado de constitucionalidade, perdem-se os filtros próprios assembleares que funcionam como verdadeiras restrições à arbitrariedade e ao voluntarismo/subjetivismo singular. O Tribunal não possui, e isso

75 POSNER, Richard A. How judges think. Cambridge: Harvard University Press, 2010, p. 30.

76 Sobre o comportamento estratégico do Ministro-relator no momento em que libera o processo para a pauta de julgamento, confira SILVA, Virgílio Afonso da. "Um voto qualquer?" O papel do Ministro Relator na deliberação no Supremo Tribunal Federal. Revista Estudos Institucionais, vol. 1, 1, p. 180-200, 2015.

77 ARGUELHES, Diego Werneck; RIBEIRO, Leandro Molhano. O Supremo Individual: mecanismos de atuação direta dos Ministros sobre o processo político. Direito, Estado e Sociedade, n. 46, p. 121-155, jan/jun, 2015.

78 FALCÃO, Joaquim; ARGUELHES, Diego Werneck. Onze supremos: todos contra o plenário. In: FALCÃO, Joaquim; ARGUELHES, Diego Werneck; RECONDO, Felipe (org.). Onze supremos: o supremo em 2016. Belo Horizonte: Letramento: Casa do Direito: Supra: Jota: FGV Rio, 2017, p. 20-28.

79 MELLO, Patrícia Perrone Campos. "A vida como ela é": comportamento estratégico nas cortes. Rev. Bras. Polít. Públicas, Brasília, v. 8, $n^{\circ}$ 2, p.688-718, 2018. Sobre o poder da pauta da Presidência, confira ARGUELHES, Diego Werneck. A pauta da presidente Cármen Lúcia. In: FALCÃO, Joaquim; ARGUELHES, Diego Werneck; RECONDO, Felipe (org.). Onze supremos: o supremo em 2016. Belo Horizonte: Letramento: Casa do Direito: Supra: Jota: FGV Rio, 2017, p. 60-62.

80 ARGUELHES, Diego Werneck; RIBEIRO, Leandro Molhano. O Supremo Individual: mecanismos de atuação direta dos Ministros sobre o processo político. Direito, Estado e Sociedade, n. 46, p. 121-155, jan/jun, 2015.

81 ARGUELHES, Diego Werneck; RIBEIRO, Leandro Molhano. O Supremo Individual: mecanismos de atuação direta dos Ministros sobre o processo político. Direito, Estado e Sociedade, n. 46, p. 121-155, jan/jun, 2015. 
precisa ficar claro, liberdade para decidir em desconformidade com o Direito ${ }^{82}$, por razões subjetivas de seus membros individualizados, por uma busca de uma decisão "mais justa"83 ou mesmo com base em uma discricionariedade ampla (política).

Apura-se, deste modo, a consolidação de um comportamento estratégico dos magistrados que utilizam os poderes monocráticos como mecanismo de atingimento de seus objetivos, sem qualquer vinculação ao papel institucional da Corte. Há inegável desequilíbrio do cenário institucional quando os componentes do tribunal agem isoladamente, deixando de possuir o conceito de tribunal e proferem decisões que não espelham a posição do colegiado.

Assim, ao priorizar a deliberação individual, o Supremo claramente efetuou uma escolha política: robusteceu o protagonismo dos Ministros nas suas preferências políticas-ideológicas e mitigou o papel institucional da Corte.

\section{CONSIDERAÇÕES FINAIS}

A Suprema Corte tem se mostrado como um tribunal moroso, imprevisível e seletivo, fruto da demasiada extensão competencial que o aprisiona simultaneamente em primeira instância, em tribunal de revisão/cassação e em Corte Constitucional.

A imoderada utilização do formato individual decisório, que inicialmente era adotado na esfera recursal, difundiu-se e alcançou as demais competências do Supremo Tribunal Federal e, nesse trajeto, estendeu a racionalidade da deliberação monocrática para o controle concentrado de constitucionalidade. A análise da série histórica (2010-2018) demonstra que as decisões monocráticas cresceram $304,14 \%$ nas ADI e $413,63 \%$ nas ADPF.

O processo de deliberação coletiva é um diálogo de surdos, onde não há debate, argumentação e persuasão, mas tão somente transmissão oral de uma decisão previamente preparada por escrito, ocasião em que os Ministros estão presentes para defender suas posições preexistentes e não para dialogar na construção do consenso.

82 Como bem assinalam Rosivaldo Toscano dos Santos Júnior e Lenio Luiz Streck, "o juiz é um ator político, no sentido em que representa o Poder Constituído. Mas ele não age ao alvedrio das próprias regras que o legitimaram como tal agente de poder. Assim como não há liberdade absoluta, o juiz é livre, por assim dizer, para decidir, mas sempre dentro de uma esfera de normatividade que constitui seu mundo decisório. Se há o dever constitucional de fundamentar suas decisões, há, acima disso, a necessidade de respeitar as regras do jogo democrático" (SANTOS JÚNIOR, Rosivaldo Toscano dos; STRECK, Lenio Luiz. Vontade de poder versus normatividade: o que o nazismo nos ensina? Revista Novos Estudos Jurídicos - Eletrônica, vol. 21, n. 2, mai-ago 2016, p. 416).

83 A respeito dos "heróis" e "justiceiros", frequentemente encontrados em determinados órgão públicos, que buscam desviar os ditames normativos em benefício de uma pretensa justiça, Emerson Gabardo bem assinala que "a 'ilusão da justiça' é uma decorrência da falsa percepção de que os agentes públicos podem, a partir de uma consciência pura, austera e imparcial, refletir os anseios de felicidade dos demais indivíduos para além de uma ordem deliberada e a priori estabelecida como regra geral objetiva" (GABARDO, Emerson. Os perigos do moralismo político e a necessidade de defesa do direito posto na Constituição da República de 1988. A\&C - Revista de Direito Administrativo \& Constitucional, Belo Horizonte, a. 17, n. 70, out./dez. 2017, p.85). 
A fragmentação do Supremo não resulta somente da colossal quantidade de processos e os escassos meios para julgá-los, senão da escolha deliberada de os Ministros não deliberarem coletivamente. A utilização irrefreada das decisões monocráticas, mais que um paliativo para tentar dar vazão aos processos, consubstancia-se em um verdadeiro comportamento estratégico individual dos Ministros. É disfuncional um modelo que outorga poder monocrático - que provém da instituição - para decidir em desacordo com a própria instituição e, sobretudo, que não possua ferramentas de constrangimento para evitar que tal situação ocorra. O Plenário, verdadeiro filtro moderador das posições e vieses individuais, cede ante a voracidade e o arbítrio individuais que ficam alijados de qualquer forma de controle, prestação de contas e sanção.

\section{REFERÊNCIAS BIBLIOGRÁFICAS}

ARGUELHES, Diego Werneck. A pauta da presidente Cármen Lúcia. In: FALCÃO, Joaquim; ARGUELHES, Diego Werneck; RECONDO, Felipe (org.). Onze supremos: o supremo em 2016. Belo Horizonte: Letramento: Casa do Direito: Supra: Jota: FGV Rio, 2017, p. 60-62.

; RIBEIRO, Leandro Molhano. O Supremo Individual: mecanismos de atuação direta dos Ministros sobre o processo político. Direito, Estado e Sociedade, n. 46, p. 121-155, jan/jun, 2015.

RIBEIRO, Leandro Molhano. Ministrocracia: O Supremo Tribunal Federal e o processo democrático brasileiro. Novos Estudos Cebrap, v. 37, p. 13-32, jan.-abr, 2018.

RIBEIRO, Leandro Molhano. Preferências, Estratégias e Motivações: pressupostos institucionais de teorias sobre comportamento judicial e sua transposição para o caso brasileiro. Revista Direito e Práxis. Vol. 4, n. 7, p. 85-121, 2013.

; HARTMANN, Ivar A. Mendes e Lula: uma liminar contra o Plenário do Supremo. In: FALCÃO, Joaquim; ARGUELHES, Diego Werneck; RECONDO, Felipe (org.). Onze supremos: o supremo em 2016. Belo Horizonte: Letramento: Casa do Direito: Supra: Jota: FGV Rio, 2017, p. 41-43.

BARROSO, Luís Roberto. O Supremo Tribunal Federal em 2016: o ano que custou a acabar. Disponível em: https://www.conjur.com.br/dl/retrospectiva-2016-barroso-parte.pdf. Acesso em: 16 jul. 2019.

BRASIL. Supremo Tribunal Federal. Estatísticas do STF. Disponível em: http://www.stf.jus.br/portal/cms/ verTexto.asp?servico=estatistica\&pagina=decisoesinicio. Acesso em: 09 jul. 2019.

BRASIL. Supremo Tribunal Federal. Estatísticas do STF: AI, ARE e RE. Disponível em: http://www.stf.jus.br/ portal/cms/verTexto.asp?servico=estatistica\&pagina=competenciarecursal. Acesso em: 18 jul. 2019.

BRASIL. Supremo Tribunal Federal. Estatísticas do STF: ARE, Al e RE. Disponível em: http://www.stf.jus.br/ portal/cms/verTexto.asp?servico=estatistica\&pagina=REAIProcessoDistribuido. Acesso em: 16 jul. 2019.

BRASIL. Supremo Tribunal Federal. Estatísticas do STF: Pesquisa por classe. Disponível em: http://www.stf.jus. $\mathrm{br} /$ portal/cms/verTexto.asp?servico=estatistica\&pagina=pesquisaClasse. Acesso em: 16 jul. 2019.

BRASIL. Supremo Tribunal Federal. ADI 5017: Andamentos. Disponível em: http://www.stf.jus.br/portal/cms/ verTexto.asp?servico=estatistica\&pagina=decisoesinicio. Acesso em: 09 jul. 2019.

BRASIL. Supremo Tribunal Federal. Medida Cautelar na Ação Declaratória de Constitucionalidade 54/DF. Relator: Ministro Marco Aurélio, 19 de dezembro de 2018. Disponível em: http://portal.stf.jus.br/processos/ downloadPeca.asp?id=15339307371\&ext=.pdf. Acesso em: 07 jul. 2019. 
BRASIL. Supremo Tribunal Federal (Presidência). Medida Cautelar na Ação Direta de Inconstitucionalidade 5017. Ministro Joaquim Barbosa, 17 de julho de 2013. Disponível em: http://www.stf.jus.br/arquivo/cms/ noticiaNoticiaStf/anexo/ADI_5017_Liminar.pdf. Acesso em: 07 jul. 2019.

BRASIL. Supremo Tribunal Federal. Habeas Corpus 153466/PE. Relator: Ministro Gilmar Mendes. Disponível em: http://portal.stf.jus.br/processos/downloadPeca.asp?id=313882237\&ext=.pdf. Acesso em: 07 jul. 2019.

BRASIL. Supremo Tribunal Federal. Habeas Corpus 163906/MG. Relator Ministro Ricardo Lewandowski. Disponível em: http://portal.stf.jus.br/processos/downloadPeca.asp?id=15339137071\&ext=.pdf. Acesso em: 07 jul. 2019.

CHUEIRI, Vera Karam; MACEDO, José Arthur Castillo. Teorias constitucionais progressistas, backlash e vaquejada. Seqüência (Florianópolis). n. 80, p. 123-150, dez. 2018.

DALLARI, Dalmo de Abreu. O poder dos juízes. São Paulo: Saraiva, 1996.

DONNELLY, Tom, Making Popular Constitutionalism Work (November 21, 2011). Wisconsin Law Review, Vol. 2012; Harvard Public Law Working Paper No. 11-29. Available at SSRN: https://ssrn.com/abstract=1962580.

DWORKIN, Ronald. $O$ império do direito. 3. ed. São Paulo: Martins Fontes, 2014

EPSTEIN, Lee; SEGAL, Jeffrey; SPAETH, Harold. The norm of consensus on the U.S. Supreme Court. American Journal of Political Science, vol. 45, n. 2, p. 362-377, Apr., 2001.

FALCÃO, Joaquim; ARGUELHES, Diego Werneck. Onze supremos: todos contra o plenário. In: FALCÃO, Joaquim; ARGUELHES, Diego Werneck; RECONDO, Felipe (org.). Onze supremos: o supremo em 2016. Belo Horizonte: Letramento: Casa do Direito: Supra: Jota: FGV Rio, 2017, p. 20-28.

; CERDEIRA, Pablo Camargo; ARGUELHES, Diego Werneck. I Relatório Supremo em números: o múltiplo Supremo. RDA - Revista de Direito Administrativo. Rio de Janeiro, v. 262, p. 399-452, jan./abr. 2013.

FORSTER, João Paulo K.; HAEBERLIN, Mártin. O "iluminismo constitucional": A atuação do Supremo Tribunal Federal entre a autocontenção e o ativismo judicial. Revista Novos Estudos Jurídicos - Eletrônica, vol. 24, n. 2, p. 616-642, mai-ago 2019.

GABARDO, Emerson. Os perigos do moralismo político e a necessidade de defesa do direito posto na Constituição da República de 1988. A\&C - Revista de Direito Administrativo \& Constitucional, Belo Horizonte, a. 17, n. 70, p. 65-91, out./dez. 2017.

GOMES, Juliana Cesario Alvim; NOGUEIRA, Rafaela; ARGUELHES, Diego Werneck. Gênero e comportamento judicial no supremo tribunal federal: os ministros confiam menos em relatoras mulheres?. Rev. Bras. Polít. Públicas, Brasília, v. 8, nº 2, p. 854-876, 2018.

GOMES, Luiz Flávio. A dimensão da magistratura: no estado constitucional e democrático do direito. São Paulo: RT, 1997.

HARTMANN, Ivar Alberto; FERREIRA, Lívia da Silva. "Ao relator, tudo: o impacto do aumento do poder do ministro relator no Supremo". Revista Opinião Jurídica, v. 13, n. 17, pp. 268-283, 2015.

KAZMIER, Leonard J. Estatística aplicada à economia e administração. Trad. Carlos Augusto Crucius; Rev. Técnica Jandyra M. Fachel. São Paulo: Pearson Makron Books, Coleção Schaum, 2004.

LIMA, Jairo. Emendas constitucional inconstitucionais: democracia e supermaioria. Rio de Janeiro: Lumen Juris, 2018.

LOPES, Felipe de Mendonça. Television and Judicial Behavior: Lessons from the Brazilian Supreme Court. Economic Analysis of Law Review, v. 9, n. 1, p. 41-71, jan-abr, 2018.

MARINONI, Luiz Guilherme. O julgamento nas cortes supremas: precedentes e decisão do recurso diante do novo CPC. São Paulo: RT, 2015. 
Precedentes obrigatórios. 2. ed. São Paulo: RT, 2011.

MELLO, Patrícia Perrone Campos. "A vida como ela é": comportamento estratégico nas cortes. Rev. Bras. Polít. Públicas, Brasília, v. 8, n² 2, p. 688-718, 2018.

NETO, José Mário Wanderley Gomes; LIMA, Flávia Danielle Santiago; OLIVEIRA, Tassiana Moura de. Between Individual Decisions and Collegiate Deliberations: Deciding How To Decide, Influencing the Outcome. Seqüência (Florianópolis). n. 81, p. 10-31, abr. 2019.

PONTES DE MIRANDA, Francisco Cavalcanti. Comentários ao código de processo civil. Tomo VII. Rio de Janeiro: Forense, 1975.

POSNER, Richard A. How judges think. Cambridge: Harvard University Press, 2010.

POST, Robert; SIEGEL, Reva. Roe Rage: Democratic Constitucionalism and Backlash. Harvard School, Public Law Working Paper n. 31.

PÜSCHEL, Flavia Portella. Racionalidade coletiva no STF e precedentes vinculantes: o exemplo do conceito de vida na ADPF n. 54. Revista Novos Estudos Jurídicos - Eletrônica, vol. 24 - n. 2, p. 536-561, mai-ago, 2019.

REZENDE, Maurício Côrrea de Moura. Democratização do poder judiciário no Brasil. São Paulo: Contracorrente, 2018.

SANTOS JÚNIOR, Rosivaldo Toscano dos; STRECK, Lenio Luiz. Vontade de poder versus normatividade: o que o nazismo nos ensina? Revista Novos Estudos Jurídicos - Eletrônica, vol. 21, n. 2, p.393-420, mai-ago, 2016.

SILVA, Virgílio Afonso da. O STF e o controle de constitucionalidade: deliberação, diálogo e razão pública. Revista de Direito Administrativo, v. 250, p. 197-227, 2009.

"Um voto qualquer?" O papel do Ministro Relator na deliberação no Supremo Tribunal Federal. Revista Estudos Institucionais, vol. 1, 1, p. 180-200, 2015.

De quem divergem os divergentes: os votos vencidos no Supremo Tribunal Federal. Direito, Estado e Sociedade, n. 47, p. 205-225, jul/dez 2015.

O relator dá voz ao STF? Uma réplica a Almeida e Bogossian. Revista Estudos Institucionais, vol. 2, 2, p. 648-669, 2016.

SOUTO, João Carlos. Suprema corte dos Estados Unidos: principais decisões. 3. ed. São Paulo: Atlas, 2019.

SUNSTEIN, Cass. R. If people would be outraged by their rulling should judges care? (John M. Olin Program in Law and Economics Working Paper No. 332, 2007.

TOMIO, Fabrício Ricardo de Limas; ROBL FILHO, Ilton Norberto. Accountability e independência judiciais: uma análise da competência do Conselho Nacional de Justiça (CNJ). Revista de Sociologia e Política [online]. vol.21, n.45, pp. 29-46, 2013.

VIEIRA, Oscar Vilhena. "Supremocracia". Revista Direito GV, São Paulo, v. 4, n. 2, p. 441-463, jul/dez. 2008.

ZAFFARONI, Eugenio Raúl. Poder judiciário: crise, acertos e desacertos. São Paulo: RT, 1995.

ZARONI, Bruno Marzullo. Deliberação e julgamento colegiado: uma análise do processo decisório do STF. 2015. Tese (Doutorado em Direito) - Faculdade de Direito, Universidade Federal do Paraná, Curitiba, 2015.

Recebido em: 02/12/2019

Aprovado em: 19/03/2021 